\title{
PROMOTING PATRIARCHAL POLITICS IN DAPHNE DU MAURIER'S REBECCA
}

\author{
Thohiriyah \\ Universitas Negeri Semarang \\ thohiriyah@mail.unnes.ac.id
}

\begin{abstract}
This paper aims to analyze a patriarchal politics performed by the male antagonist named Maxim de Winter in his life of domestic partnership with a female protagonist, Rebecca, elucidated in Daphne du Maurier's novel entitled Rebecca. The concept of promotion of patriarchal domination is done through deconstructive narration. At first, the novel constructs a narration by putting the woman in a privileged position. However, this position is later dismantled by male domination. This paper employs some methods consisting of close reading, qualitative analysis, and deconstructive analysis. The result shows that woman's privileged position is only used as a medium for a man to prove his domination and promote patriarchal politics in the form of power struggle.
\end{abstract}

Key words: patriarchal politics, power, Rebecca

\section{Introduction}

Rebecca (1991) written by Daphne du Maurier (1907-1989), a British novelist, talks about a life of domestic partnership between female protagonist named Rebecca, and male antagonist, Maxim de Winter. The couple lived in a great mansion, Manderley. Rebecca died in a boat accident just a year before her husband, Maxim de Winter, married to a young woman named Caroline or the second Mrs. de Winter.

Rebecca's death is in fact caused by a by-designed accident in which Maxim de Winter is the one behind the death scene. Rebecca was shot dead by Maxim de Winter and he made it as if she got a boat accident. $\mathrm{He}$ acclaimed that his marriage with Rebecca was full of manipulation.

Although Rebecca had died, she was described as powerful and dominant. Her domination and perfection were proved by Menderley in which all decorations reflect Rebecca's possession of the mansion. The second Mrs. de Winter could not even change the decoration. Every time she tried to change
Manderley, Mrs. Denver, the sinister housekeeper, always prevented her action by telling how Rebecca run it. Mrs. Denver's action implies to show how incapable the second Mrs. de Winter was. On the other hand, Maxim de Winter was haunted by her late wife. One day, when the ball was conducted in Manderley, the second Mrs. de Winter put on a white gown and it made Maxim thought that his second wife was Rebecca.

This novel at first narrates Rebecca's influence and domination over Manderley and Maxim de Winter. However, Rebecca's domination is told after her death through her housekeeper. Rebecca's domination doesn't exactly show how powerful he is instead of only being a medium of male antagonist to promote his patriarchal domination. To analyze how the male antagonist dismantles female's power, the concept of deconstructive analysis is used. Another concept to support the analysis is the concept of domination, patriarchal dominance, and politics. 


\section{Previous Study}

There are several studies conducted by the previous researchers which concern more on intrinsic analysis of the novel such as characters and characterizations, and narration strategy. Parey (2015) reveals a haunting figure of Rebecca, while Linkin (2016) focuses on the narrator's deceptive strategy in Rebecca revealing the narrator's shift and character in telling the characters under the narratological lens. Another research conducted by Morden (2016) concerns on female identity construction in Rebecca. A study dealing with patriarchal politics promotion through dismantling female's position and dominant character is not conducted yet. Thus, this research is aimed to show that the haunting character of Rebecca and the identity formation of the female protagonist are only media for the male to promote his sense of patriarchal politics.

\section{Deconstructive Theory}

Deconstruction thought adopts Derrida's ideas which he borrows structuralism analysis as "the basis of and starting point". Deconstruction provides another alternative meaning of the literary work since deconstruction has characteristic of polyinterpretation. Deconstruction starts firstly with the establishment of binary opposition. Secondly, establishing the binary opposition, the next step is deciding the hierarchical position i.e. privileged and non-privileged positions. Then, after the hierarchical position has been decided, the next step is, subverting the hierarchical position (Bressler,
1999). Finally, alternative meaning can be embraced.

\section{Method and Data}

The method employed to analyze the data is using deconstructive-based steps. The deconstructive steps in analyzing the novel are as follows: first, analyzing the text structurally by using the structuralist approach to figure out the oppositions; second, reversing the outset meaning which has been structurally analyzed by using deconstruction approach. By using the deconstruction approach it is hoped that I can reveal another assumption showing alternative meaning behind the constructed text. Meanwhile, the primary data used in this paper is gained in the novel in the form of excerpts.

\section{Results and Discussion}

Rebecca: A Premature Assumption of Powerful Woman

In Rebecca, there is a polemic between woman and man that can be seen in its plot structure. The plot is dominated by serious conflict afflicting women in her relation to men in marriage life. The serious marriage life conflict is reflected in the life of Rebecca and her husband's - Maximilian de Winter (Maxim de Winter).

In Rebecca, Maurier describes powerful Rebecca's domination in marriage life. Although Rebecca has already died, her domination over Manderley and her life still exist. Man character, who is represented by Maximilian de Winter, Rebecca's husband, 
seems so powerless to defeat Rebecca's domination. The aforementioned plot structure leads to the premature assumption that woman has powerful domination over man in domestic life. Below is a scheme showing Rebecca's plot structure based on structural analysis.

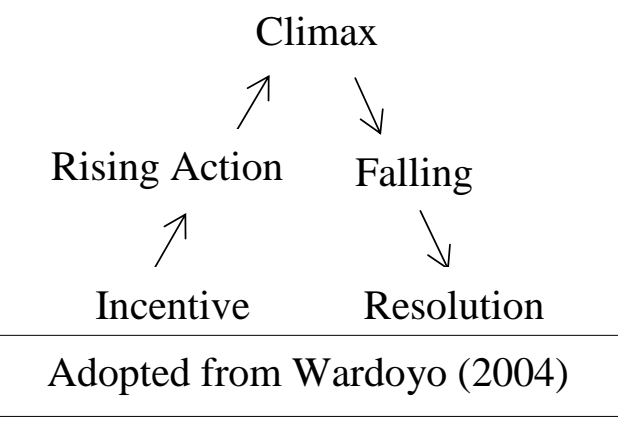

Picture 1. Rebecca's plot structure scheme

Incentive Moment in Rebecca starts when Caroline and Mr. de Winter meet each other in Monte Carlo. Then the Raising Action happened when they both decide to get married and Caroline becomes Mrs. de Winter. they both live in Manderley. Mrs.de Winter cannot able to adapt to the life of Manderley so that she tends to be weak and powerless. In addition, she cannot able to avoid Rebecca's shadow in Manderley. Those aforementioned Mrs. de Winter / Caroline's weak and powerless characters lead to the Climax of the story i.e. the internal conflict between her and her husband, Maxim de Winter. Maxim cannot escape from the shadow of Rebecca's domination. It makes him become temperament.

Daphne du Maurier, Rebecca, Renarrated by Margaret Tarner (1991):

\footnotetext{
"All my memories are unhappy" (p.13).

"I found out the truth five days after we were married. We were in the hills near Monte Carlo. It was the same place I went to woth you. Do you remember? She sat there in
}

the car and told me terrible, evil things about herself. Thisngs that I could not tell anyone."

"She knew that I would never divorce her" (p.90).

I thought about Manderley too much,...I told her that Manderley was mine" (p.91).

"And she smiled at me again. She was smiling when I killed her. the bullet went through her heart" (p.92).

Maxim cannot forget Rebecca since he has a very unpleasant memory with her dealing with her domination in their marriage and domestic life. Maxim is being traumatic person caused by Rebecca. His trauma triggers him to kill Rebecca by shooting her. De winter's Trauma cannot be erased although Rebecca had already died. Rebecca causes so many troubles for de Winter's life. De Winter lives in fear because of his conspiracy in killing Rebecca considered as a serious crime. His conspiracy brings to the falling action plot i.e. Mr. de Winter Judgement. The litigation is closed by the resolution namely Mr. de Winter's impunity. Mr. de Winter gets the impunity since the court cannot prove his fault.

In the above plot structure, there can be seen that there is a binary opposition between woman and man. The woman is represented by Rebecca, while the man is represented by Maxim de Winter. Rebecca has dominant power in the domestic arena in marriage life. Hence, The plot structure proofs that woman has powerful domination over the man.

The plot structure cannot be separated from Rebecca's action. As the centre of the story, Rebecca actuates and leads the story to the tension of the story. The tension is divided into two that are internal and interpersonal conflicts of the character of $\mathrm{Mr}$. De Winter. The internal conflict possessed by 
Mr. De Winter deals with psychological depression, while the interpersonal conflict of him is the messy relation with his young wife, Caroline. The marriage life of Mr. De Winter and Caroline is in the shadow of Rebecca which resulted in isolated marriage life. De Winter's incapability of surrendering the shadow of Rebecca indicates man's impotency in controlling power. Man who is identically attributed to a superpower is being subdued by the woman.

Then, it might be concluded that the novel entitled Rebecca highlights the issue of woman domination over a man. However, it is too early to conclude that woman has strong domination over a man. The aforementioned structural analysis must be dug out more in order to find out the real assumption of Rebecca's alternative meaning.

\section{Rebecca: A Means of Promotion of Patriarchal Politics}

Referring to the above analysis namely in the falling action till resolution sessions, there is a possibility of rejecting the above premature conclusion. Thus, it is needed to do further analysis of the text in order to get the real meaning of Rebecca. To figure out the implicit alternative meaning of the novel, the decontruction approach is used.

The established binary oppositions are the opposition between woman and man represented by Rebecca and Maxim de Winter. The structural analysis places the woman in a privileged position, while the man is in a non-privileged position. A woman is placed in a privileged position because the woman has power in dominating man in marriage life, while the man is being placed in a non-privileged position because of his incompetency to control life. For detail, the binary opposition is clearly described by the table below.
Table 1. Oppositional structural analysis of female protagonist's vs male antagonist's positions

\begin{tabular}{ll}
\hline \multicolumn{2}{c}{ Structural analysis } \\
\hline Female protagonist & Male Protagonist \\
\hline Privileged position & $\begin{array}{l}\text { Non-privileged } \\
\text { position }\end{array}$ \\
\hline Rebecca & Mr. De Winter \\
\hline Woman & Man \\
\hline Exist, dominant, & $\begin{array}{l}\text { toneless, minor } \\
\text { (being dominated), } \\
\text { powerful }\end{array}$ \\
\hline
\end{tabular}

Referring to the third step of deconstruction, the oppositions above then can be subverted to be as follows:

Table 2. Subverted position analysis of female protagonist vs male antagonist

\begin{tabular}{ll}
\hline \multicolumn{2}{c}{ Deconstruction } \\
\hline Female protagonist & Male Protagonist \\
\hline Privileged position & $\begin{array}{l}\text { Non-privileged } \\
\text { position }\end{array}$ \\
\hline Mr. De Winter & Rebecca \\
\hline Man & Woman \\
\hline Exist, powerful & died, powerless \\
\hline
\end{tabular}

From the above subversion table, it can be seen that man successfully takes control over woman power. It is seen by the characters in the novel in which Maxim as the man character succsessfully subdues Rebecca. By conquering Rebecca, now, Maxim places himself in the privileged position. The privileged position indicates the existence of Maxim. Besides, it indicates the power of Maxim. On another side, Rebecca's death leads her to be in the nonprivileged position. Death has symbolized the loss of the woman. This proposition is supported by the below variant structure of falling action and resolution plot which are telling the final resolution of the story of Maxim's safe and impunity. 
Mr. De Winter $\rightarrow$ Conspiration of Rebecca's death $\rightarrow$ Safe

From the structure above, it can be seen that man who is represented by Maxim de Winter is safe and get impunity from the crime he had committed to. If indeed the novel titled Rebecca brings meaning to women's ability to dominate the lives of men, the meaning seems to be rejected by the structure presented in the falling action and resolution above. If indeed the novel focuses on the assumption of the defense of women's position, the falling action and resolution in the story suppose to end in severe punishment for the man who has committed crimes.

The initial binary opposition structure established by structural analysis is now being deconstructed. The man is now not in the non-privileged position but the privileged position swapping the woman's position. The woman who is previously in the privileged position, now it is changed to be in the nonprivileged position or marginal. The structure of the privileged position of woman is now partially dismantled. The destruction of the structure is not only dismantling the privileged position of women but also getting rid of the structure of power domination that woman has. Considering the resolution structure for the plot climax that shows the triumph of man, it can be concluded that actually, the text is trying to promote political patriarchy.

The existence of the term "patriarchy" refers to the dichotomy of woman and man. the term woman and man refers to the "sex-based classification" (Warnke, 2007, p. 4). Thus, the term patriarchy is the terminology used in a social life where men are placed as the main authority figure. Politics signifies not only "elections" and "campaign" but also signifies how a person or a group of people attempt to change and form the decision. Politics makes a person or group of people participate actively in the "power struggle" (Putman, 2008, p. 7).

In Rebecca, the tendency of patriarchal politics done by the man character i.e. Maxim de Winter. The power struggle is done by taking power over the woman. In the power struggle, Maxim actively makes radical decision including killing his political opponent, Rebecca.

\section{Bullet VS Heart}

The marriage formed by Maxim is such a conditional marriage with the ultimate aim is power. Maxim's world view to possess Manderley leads him to place his wife, Rebecca, not as the wife but the adversary. Maxim de Winter who during his life was being dominated by Rebecca, the ruler of Manderley, starts actively doing "power struggle" by killing his opponent, Rebecca.

"The bullet went through her heart" (du Maurier, 1991, p. 92).

The quotation above shows the power struggle made by Mr. de Winter in gaining power. Mr. de Winter decides to fire a bullet into his adversary's heart because his goal is "Manderley was mine" (du Maurier, 1991, p. 91). Manderley is a symbol of power possession. According to Risakotta (2002/2003), "power is closely related to violence, domination, and pressure." It means that power is the ability to force the desire or demand of authority, even by using violence. Violence is, then, considered to be something close to domination. Risakotta (2002/2003) defines domination as a political principle for conquering and controlling something by exploiting somebody in order to gain economic benefits or power.

In gaining his desire of possessing Manderley, Maxim uses the violence that is physical violence namely by shooting Rebecca. By possessing Manderley, it means 
someone has political and economical power. Seen from the point of view of political power, a person who controls Manderley has the power to place himself as the ruler who can dominate the dwellers of Manderley. From an economic perspective, Manderley is such an attribute of wealth. By the wealth that he is now possessed, Maxim has access to dominate the business that previously handled by Rebecca.

\section{Conclusion}

By using the deconstructive approach, the first meaning of Rebecca as a powerful woman figure in the story is partially dismantled. Rebecca is a means for the man to show his existence. Self-existence can be obtained with power due to power one can perform the domination of others. In the power struggle, man tends to place the woman as an opponent. In such a relation, man does not hesitate to commit radical acts with the intention to seize power from his opponent. When the power has already possessed, the man is able to show his existence and domination. No matter as strong as any woman, man is someone who clings to power till the end. That phenomenon has been described in the novel entitled Rebecca which Maxim de Winter successfully subdues Rebecca by using the bullet in order to be dominant and powerful. By using Rebecca, Maxim successfully promoting patriarchal politics with its successful goal of possessing power and domination.

\section{References}

Bressler, C.N. (1999). Literary Criticism: An Introduction to Theory and Practice. New Jersey: Prentice Hall, Inc.

du Maurier, Daphne. (1991). Rebecca. Renarrated by Margaret Tarner. Jakarta: Dian Rakyat.

Linkin, H.K. (2016). The Deceptively Strategic Narrator of Rebecca. Journal of Narrative Theory, Volume 46, Number 2, Summer 2016, pp. 223-253.

Parey, Armelle. (2015). Daphné du Maurier's characters in Rebecca living on in Mrs de Winter. E-rea - Revue électronique d'études sur le monde anglophone, Laboratoire d'Études et de Recherche sur le Monde Anglophone, 2015, 10.4000/erea.4731.hal-02274534

Putman, John C. (2008). Class and Gender Politics in Progressive-Era Seattle. Nevada: University of Nevada Press.

Risakotta, Adeney. B. (2002/2003). "Teori Kekuasaan dari Bawah". In "RENAI Jurnal Politik Lokal dan Sosial Humaniora Indonesia.

Wardoyo, Subur. (2004). "A Roadmap into Liteary Reasearch Method" in The Tapestry of English Language Teaching and Learning in Indonesia. Malang: State University of Malang.

Warnke, Georgia. (2007). After Identity: Rethinking Race, Sex and Gender. Cambridge: Cambridge University Press. 